\title{
Pemberitaan Hoax di Media Online Ditinjau dari Konstruksi Berita dan Respon Netizen
}

\author{
Dendy Suseno Adhiarso, Prahastiwi Utari dan Yulius Slamet \\ Program Magister Ilmu Komunikasi FISIP Universitas Sebelas Maret Surakarta \\ J1. Ir. Sutami No.36A, Jebres, Kota Surakarta, Jawa Tengah 57126 \\ Email : dendysuseno@gmail.com
}

\begin{abstract}
Online media / internet has an important role that lies in its ability to present news about the development of society that can bring modern life at this time. Because the individual is very enthusiastic by the media media messages are very strong in shaping public opinion. The theory used in this research is communication theory, mass communication, news development, netizen response, online media. This research uses quantitative descriptive analysis. Data technique in this research using online data technique. Based on the analysis and discussion can be concluded (1) The construction of news has a positive effect on the news of deceit in online media. This means that the construction of news that is loaded and created by online media will affect the spread of news fraud in the online media; (2) The netizen response positively affects the coverage of online media deception. The more netizens arise, the more deceitful news will be broader and more liars without reference to journalism; (3) News construction and netizen responses have a positive and significant influence on the deception in online media. This means that these two variables provide a significant influence in the news of deceit in online media.
\end{abstract}

Keywords: News Construction, Netizen Response, Hoax Reporting

\begin{abstract}
Abstrak
Media online/internet mempunyai peranan penting yang terletak pada kemampuannya untuk menyajikan berita-berita tentang perkembangan masyarakat yang bisa mempengaruhi kehidupan modern pada saat ini. Oleh karena individu diyakini sangat terpengaruh oleh pesan-pesan media mengingat media dianggap sangat kuat dalam membentuk opini masyarakat. Teori yang digunakan dalam penelitian ini adalah teori komunikasi, komunikasi massa, konstruksi berita, respon netizen, media online. Riset ini menggunakan analisis deskriptif kuantitatif. Teknik pengumpulan data dalam penelitian ini menggunakan teknik pengumpulan data online. Berdasarkan analisis dan pembahasan dapat disimpulkan bahwa (1) Kontruksi berita berpengaruh positif terhadap pemberitaan hoax di media online. Artinya konstruksi berita yang dimuat dan diciptakan oleh media online akan mempengaruhi penyebaran pemberitaan hoax di media online; (2) Respon netizen berpengaruh positif terhadap pemberitaan hoax di media online. Arinya semakin banyak netizen yang merespon pemberitaan hoax, maka peredaraan pemberitaan hoax akan lebih luas dan lebih liar tanpa berpedoman pada etika jurnalitik; (3) Konstruksi berita dan respon netizen memiliki pengaruh positif dan signifikan terhadap pemberitaan hoax di media online. Artinya kedua variabel tersebut memberikan pengaruh yang cukup signifikan dalam pemberitaan hoax di media online.
\end{abstract}

Kata Kunci: Konstruksi Berita, Respon Netizen, Pemberitaan Hoax 


\section{Pendahuluan}

Media massa merupakan hasil karya budaya manusia yang semakin hari semakin berkembang dan meluas. Media massa menjadi sarana untuk menyebarkan pesan/informasi kepada masyarakat. Seiring perkembangan informasi yang sedang berkembang saat ini menjadikan peran media massa semakin dibutuhkan dan berita pun menjadi sangat penting bagi masyarakat. Karena media massa menyajikan peristiwa-peristiwa seputar kehidupan masyarakat baik yang bersifat nasional maupun internasional, sehingga dengan adanya berita manusia mengetahui, memahami, dan mengerti segala sesuatu yang terjadi di sekitar dan di dunia.

Materi berita yang disajikan dalam media massa merupakan daya tarik yang mampu mengundang keingintahuan pembaca atau masyarakat. Berita yang ditampilkan dapat berupa peristiwa, kejadian, opini, ide, dan sebagainya. Berita juga dapat menarik perhatian pembaca karena peristiwa yang diangkat merupakan berita luar biasa, penting, atau mempengaruhi kehidupan masyarakat. Serta mengundang pembaca karena melibatkan emosi, empati, dan simpati.

Media massa mencakup media elektronik dan cetak. Media massa elektronik seperti televisi, radio, dan internet. Media online/internet mempunyai peranan penting yang terletak pada kemampuannya untuk menyajikan berita-berita tentang perkembangan masyarakat yang bias mempengaruhi kehidupan modern pada saat ini. Media online merupakan gudang informasi tentang kejadian atau peristiwa yang dialami oleh masyarakat dalam kehidupan bermasyarakat. Media massa dalam menyajikan informasi kepada masyarakat seyogyanya berdasarkan fakta yang ada di lapangan. Di dunia wartawan, dikenal ungkapan yang menyebutkan bahwa fakta itu adalah sakral. Makna dari ungkapan ini sebetulnya adalah sebagai ajakan bagi wartawan untuk tetap mempertahankan objektivitas, yaitu memperlakukan fakta apa adanya. Namun, berita yang disajikan dalam media massa sudah tidak mencerminkan lagi kebenaran peristiwa/ fakta yang ada, karena sudah mengalami proses kontruksi realitasnya. Apabila berita yang disajikan tidak sesuai fakta maka hal tersebut dikatakan menyebarkan berita yang mengandung kebohongan kepada publik.

Fenomena yang berkembang di masyarakat saat ini adalah penyebaran berita koax. Isu penculikan anak dengan modus pelaku pura-pura gila meresahkan dan menjadi viral di media sosial. Lebih dari sepekan, sejumlah orang yang mengidap gangguan jiwa di berbagai daerah menjadi korban amuk warga yang termakan isu pesan berantai mengenai penculikan anak. Rasa was-was menghinggapi para orangtua belakangan ini. Penyebabnya, tidak lain adalah ramainya isu tentang penculikan anak beredar melalui pesan berantai di ponsel mereka. Seorang kakek warga Kota Pontianak, Kalimantan Barat, Maman Budiman (53 tahun) tewas setelah dikeroyok massa gara-gara tersebarnya berita bohong atau hoax penculikan anak untuk dijual organ tubuhnya. Kunjungan korban ke desa tersebut untuk mengunjungi cucunya. Akan tetapi, pada saat perjalanan korban tidak tahu persis rumah anaknya sehingga kebingungan. Kebingungan korban menimbulkan kecurigaan masyarakat setempat. Karena gerak-gerik korban mencurigakan, masyarakat setempat langsung bertindak sendiri, anarkis, dan membabi buta. Tak hanya di Pontianak, isu penculikan anak juga memakan korban jiwa di Serang, Banten. Korban diduga penderita gangguan jiwa yang menjadi sasaran warga yang mendapat kabar berantai di Facebook. Korban meninggal setelah dikeroyok ratusan orang di jalan.

Selain penculikan anak, isu makar kembali ramai menjadi perbincangan hangat. Terlebih 10 tokoh ditangkap karena diduga makar. Muncul isu makar tersebut saat Kapolri Jenderal Tito Karnavian mencium adanya gerakan yang akan menunggangi aksi demo 25 November dan 2 Desember. Tito pun sejak dini menegaskan akan menindak tegas siapapun pendemo yang melanggar hukum dalam upaya penyampaian aspirasi pada demo nanti. Selain itu 
media sosial akhir-akhir ini diramaikan dengan berita-berita maupun informasi bernuansa SARA terkait gelaran aksi 'Bela Islam III' di Monas 2 Desember lalu. Banyak oknum tidak bertanggungjawab menyebarkan informasi hoax maupun isu-isu bernuansa SARA di media sosial.

Masyarakat menganggap apa yang tersaji adalah benar-benar suatu realitas, dengan mengedepankan objektivitas. Padahal dalam berita selalu terselip subjektivitas cara pandang seorang wartawan. Sehingga berita yang menyajikan suatu peristiwa terlihat tidak sesuai dengan fakta atau kebenaran. Pada akhirnya, realitas sosial tersebut dianggap sebagai "fakta", terlepas benar atau tidaknya isi pemberitaan tersebut. Karena individu diyakini sangat terpengaruh oleh pesan-pesan media karena media dianggap sangat kuat dalam membentuk opini masyarakat.

Tidak dapat dipungkiribahwaberita-berita bernuansa propokatif di media massa banyak menarik perhatian masyarakat. Pemanfaatan media sosial dan juga media massa menjadi tempat masyarakat menyampaikan opini publik yang bersifat kemanusiaan atau human interest terhadap isu-isu yang berkembang dimasyarakat. Dengan adanya internet masyarakat bisa beropini lewat media sosial baik Twitter, Facebook, Path, Line, Wechat, Websaite, Blog, E-mail dan lain sebagainya. Dengan adanya media yang berbasis internet khususnya websaite memungkinkan orang untuk melihat postingan atau unggahan berita dari media yang tentunya mengundang banyak komentar dan juga persepsi atau opini di masyarakat.

Penyajian berita dan konstruksi dari realitas yang ada mulai dibuat dengan melihat aspek-aspek yang ditonjolkan media untuk mempermudah khalayak untuk mengingat halhal tertentu yang disajikan menonjol oleh media. Dalam memublikasikan sebuah berita pada dasarnya media didasarkan kepada ideologi mereka. Cara pandang media massa dipengaruhi oleh berbagai macam aspek. Mereka mengedit, menyusun narasi, memilih judul dengan menonjolkan aspek tertentu serta mengabaikan aspek lainnya. Dalam hal ini media menjadi jembatan antara masyarakat dengan dunia. Secara rutin media massa memberikan informasi tentang peristiwa-peristiwa penting yang tengah atau telah terjadi. Perbedaan-perbedaan yang terjadi pada media massa tersebut bukanlah sesuatu yang tidak disengaja dan tanpa maksud. Perbedaan penyajian yang juga dikenal dengan nama framing media ini adalah sesuatu yang telah disetujui oleh pihak-pihak media itu sendiri. Banyak hal yang memengaruhi penyajian berita dalam media massa ke masyarakat. Wartawan sebagai orang pertama dalam produksi berita tentu cukup berperan dalam memengaruhi isi berita. Namun selain wartawan, ternyata ada juga pihak yang lebih berhak dalam menentukan isi berita dan memilih apa saja yang harus, boleh, atau tidak boleh dimuat dalam berita tersebut. Mereka adalah jajaran redaksi dan tentunya pemilik modal yang memiliki kuasa penuh terhadap media itu.

Menurut Griffin komunikasi adalah pengelolaan pesan dengan tujuan untuk menciptakan makna). Jika kita lihat definisi ini agak bersifat luas, namun tepat jika kita akan menentukan apa yang terjadi dalam setiap tahap komunikasi, yaitu berusaha mengetahui untuk apakah suatu proses komunikasi akan berhasil atau gagal baik dalam konteks komunikasi antar pribadi maupun komunikasi dalam suatu kelompok. Dengan kata lain, jika komunikasi dianggap sebagai tujuan, baik membujuk, menginformasikan, atau menghibur maka kita berkomunikasi dengan niat, dan kita dapat mencapai tujuan kita hanya dengan berinteraksi dengan seseorang

Sedangkan menurut LittleJohn perspektif tradisional (fungsionalis dan obyektif), komunikasi organisasi cenderung menekankan pada kegiatan penanganan pesan yang terkandung dalam suatu batas organisasional. Fokusnya adalah menerima, menafsirkan dan bertindak berdasarkan informasi dalam suatu konteks. Tekanannya adalah pada komunikasi sebagai suatu alat yang memungkinkan orang beradaptasi dengan lingkungan mereka. Sedangkan bila 
dipandang dari perspektif interpretif, komunikasi organisasi adalah proses penciptaan makna atas interaksi yang merupakan organisasi. Komunikasi adalah proses penciptaan makna atas interaksi yang menciptakan, memelihara dan mengubah organisasi.

Pada dasarnya komunikasi massa adalah komunikasi melalui media massa, antara lain media elektronik yaitu film, televisi dan radio, media cetak yaitu surat kabar, majalah, tabloid, dan buku. Definisi komunikasi massa yang paling sederhana yakni: komunikasi massa pada sejumlah besar orang (mass communication is messages communicated through a mass medium to a large number of people). Jay Black dan Frederick $\mathrm{C}$ menyebutkan bahwa komunikasi massa adalah sebuah proses dimana pesan-pesan yang diproduksi secara massal/tidak sedikit itu disebarkan kepada massa penerima pesan yang luas, anonim, dan heterogen. Luas disini berarti lebih besar daripada sekedar kumpulan orang yang berdekatan secara fisik sedangkan anonim berarti individu yang menerima pesan cenderung asing satu sama lain. Heterogen berarti pesan dikirim kepada orang-orang dari berbagai macam status, pekerjaan, dan jabatan dengan karakteristik yang berbeda satu sama lain dan bukan penerima pesan yang homogen.

Media massa itu sendiri mempunyai efek bagi khalayak. Efek penting yang menandai penggunaan media massa oleh khalayak adalah munculnya kesadaran dan pengetahuan mengenai suatau topik atau persoalan. Munculnya kesadaran dan pengetahuan tersebut sering tidak disadari masyarakat sebagai suatu akibat yang memang diinginkan kalangan media massa melalui penyajian suatu topik tertentu hasil dari konstruksi atas realitas. Menurut Alexis S. Tan fungsi media massa adalah memberi informasi, mendidik, mempengaruhi dan memberikan hiburan.

Media massa adalah alat untuk mengonstruksi realitas menurut pandangan konstruktivis. Sedangkan istilah konstruksi atas realitas diperkenalkan oleh sosiolog: Peter L. Berger dan Thomas Luckman, Ia menggambarkan proses sosial melalui tindakan dan interaksinya, dimana individu menciptakan secara terus menerus realitas yang dimiliki dan dialami bersama secara subjektif. Asalusul kontruksi sosial dari filsafat konstruktivis. Konstruktivis adalah suatau paham yang memandang bahwa realias atau peristiwa ialah hasil konstruksi manusia. Paham ini digunakan untuk menafsirkan dunia realitas yang ada karena terjadi hubungan sosial antara individu dengan lingkungan atau orang di sekitarnya. Konstruktivisme memandang bahwa realitas adalah hasil individu, kemudian membangun sendiri pengetahuan atas realitas yang dilihat itu berdasarkan pada struktur pengetahuan yang telah ada sebelumnya atau ia pahami. Dan konstruktivisme macam inilah yang oleh Berger dan Luckman disebut dengan konstruksi sosial. Konstruksi sosial umumnya terjadi pada pemberitaan media massa.

Menurut Berger dan Luckmann tentang teori dan pendekatan kontruksi sosial, realitas terjadi melalui tiga proses sosial, yaitu Objektivasi Realitas objektif adalah realitas yang terbentuk dari pengalaman di dunia yang dilembagakan atau mengalami proses institusional. Secara objektif yang berada di luar diri individu, dan realitas ini dianggap sebagai kenyataan. Realitas objektif sendiri terdiri dari realitas simbolis dan realitas objektif dalam berbagai bentuk. Sedangkan realitas subjektif adalah realitas yang terbentuk sebagai proses penyerapan kembali realitas objektif dan simbolis ke dalam individu melalui proses internalisasi. Dalam Proses internalisasi, realitas yang dipahami sesuai dengan pemahaman tiap individu terhadap realitas yang terjadi. Dalam proses ini terjadi dialektika antara realitas objektif dan ideologi individual. Ideologi setiap individu satu dengan yang lain tentu memiliki perbedaan. Perbedaan ini dipengaruhi oleh banyak faktor yang melatarbelakanginya, misalnya faktor agama. Orang yang bergama Islam akan memiliki pandangan yang berbeda dalam melihat sesuatu. Tentunya ini dikarenakan adanya perbedaan ajaran di dalam masing-masing agama. Selain 
faktor agama ada pula

Dalam paradigma konstruktivisme, informasi atau berita yang disampaikan kepada masyarakat terlebih dahulu melalui proses konstruksi realitas oleh rapat redaksi. Paradigma konstruktivisme memandang bahwa berita yang disampaikan oleh media massa pada dasarnya merupakan hasil konstruksi realitas dari sebuah peristiwa. Tugas wartawan, sesuai dengan ideologi media massa bersangkutan, menceritakan kembali suatu peristiwa kepada publik menurut versi sekaligus merupakan sudut pandang wartawan tersebut. Dengan demikian, berita yang ada di media massa dan sampai kepada publik adalah realitas yang sama sekali baru dan berbeda dari realitas yang ada sebagai hasil dari upaya wartawan dalam mengonstruksi realitas.

Respon dapat diartikan sebagai gambaran ingatan dari pengamatan. Menurut Jalaludin Rakhmat dalam buku Psikologi Komunikasi, sebelum terjadi tanggapan, manusia menerima sensasi pada alat inderanya. Sensasi merupakan tahap awal dalam menerima informasi. Tahap berikutnya adalah persepsi, yaitu proses pemberian makna terhadap sensasi/stimuli yang diterima oleh alat indera. Persepsi adalah pengalaman mengenai objek, peristiwa, atau hubungan yang didapat dengan menyimpulkan informasi dan menafsirkan pesan. Setelah proses sensasi dan persepsi tersebut, kemudian muncullah tanggapan. Tanggapan merupakan respon (efek) komunikan terhadap pesan yang ditawarkan.

Proses komunikasi memiliki beberapa unsur penting di dalamnya, salah satunya adalah adanya efek. Bentuk nyata efek dalam proses komunikasi adalah terbentuknya perubahan dalam berpendapat atau sikap atau perilaku khalayak setelah menerima sebuah pesan. Pengertian efek tersebut juga berlaku dalam komunikasi massa, artinya setelah netizen menerima pesan berupa berita dari media massa, maka khalayak akan memberikan efek terhadap pemberitaaan tersebut.

Menurut Onong Uchjana komunikan memberikan efek atau tanggapan terhadap pesan yang disampaikan kemudian didefinisikan sebagai berikut:

a. Efek kognitif

Efek ini berhubungan dengan pikiran atau penalaran, sehingga netizen menjadi jelas pada pesan yang dimaksud.

b. Efek afektif

Efek ini berkaitan dengan perasaan. Akibat terpaan dari media massa itu, netizen dapat merasa sedih, senang, marah, atau kecewa.

\section{c. Efek konatif}

Efek ini berkaitan dengan niat, tekad, upaya, usaha, yang cenderung menjadi suatu kegiatan atau tindakan.

Media massa memberikan gambaran mengenai alat komunikasi yang memiliki arah dan tujuan ke berbagai aspek masyarakat secara luas tak hanya masyarakat kalangan atas saja, melainkan kalangan bawah pun ikut terlibat. Istilah media massa mengacu kepada sejumlah media yang telah ada sejak puluhan tahun lalu dan tetap dipergunakan hingga saat ini, seperti surat kabar, majalah, film, radio, televisi, bahkan media massa yang saat ini adalah internet. Masyarakat dengan mudahnya mendapatkan berita aktual dengan cepat melalui internet, seperti facebook, twitter, dan media massa cetak yang masuk ke dalam media online.

Menurut Denis McQuail, media massa memiliki sifat atau karakteristik yang mampu menjangkau massa dalam jumlah besar dan luas, bersifat publik dan mampu memberikan popularitas kepada siapa saja yang muncul di media massa.

Kata online terdiri dari dua suku kata, yaitu on dan line. Menurut John M Echols dan Hasan Shadily dalam kamus Inggris Indonesia, kata on mengandung arti sedang berlangsung. Sdangkan line berarti garis, barisan, macam, tali, saluran, line, jalan, batas, garis, jurusan, perbentengan, deretan, dan tema. Online sendiri merupakan bahasa internet yang berati informasi dapat diakses di manan saja dan kapan 
saja selama ada jaringan internet. Media online bisa menampung berita teks, image, audio, dan video. Berbeda dengan media cetak yang hanya menampilkan teks dan image (gambar).

Media online adalah media yang terbit di dunia maya, istilah dunia maya pertama kali dikenalkan oleh Williams Gibson dalam novelnya yang mengartikan dunia maya yaitu realita yang terhubung secara global didukung komputer, berakses komputer, multidimensi, artificial, atau virtual.

Menurut buku Jurnalistik Terapan yang ditulis oleh Syarifuddin Yunus mengatakan: "Media online yaitu media internet seperti website, blog, dan lainnya yang terbit/tayang di dunia maya, dapat dibaca dan dilihat di internet. Media online meupakan pemain baru dalam kancah pers Indonesia, menurut beberapa sumber media online di Indonesia telah tumbuh sejak tahun 1994."

Sedangkan menurut Mc Luhan mengatakan: "Media online adalah gagasan baru dalam bermedia, namun media online masih mengikut pada media lama dan bahkan sering memanfaatkan media lama sebagai tolak ukur dalam segi isi yang diterapkan di internet. Beberapa penelitian telah mendokumentasikan kecenderungan koran-koran online untuk mengemas kembali materi-materi dari korankoran cetak."

\section{Pemberitaan Hoax Media Online}

Berdasarkan permasalahan yang telah di uraikan, maka dapat digambarkan kerangka pemikiran seperti gambar dibawah.

\section{Hipotesis Penelitian}

a. Pengaruh Konstruksi Berita terhadap Pemberitaan Hoax di Media Online

Produk utama didalam media masa adalah berita, berita menempati posisi terdepan sebagai salah satu bagian dari produk informasi tentang segala hal yang sangat berguna dan bermanfaat dalam rangka memberikan pencerahan bagi peradaban kehidupan manusia kearah yang lebih baik. Realitas-realitas peristiwa yang terjadi dalam semua aspek kehidupan yang meliputi : aspek sosial, hukum, ekonomi, poitik, agama dll semuanya merupakan bahan-bahan utama proses terjadinya suatu berita yang akan disajikan pada masyarakat. Para pemangku kepentingan dalam produk berita suatu media massa. Prinsip-prinsip jurnalisme yang senantiasa mengutamakan

$$
\mathrm{k}
$$

ualitas, faktualitas, Impartialitas senantiasa menjadi rujukan utama semua wartawan selain itu pula rambu-rambu regulasi maupun kode etik jurnalistik menjadi

Gambar 1. Kerangka Pemikiran

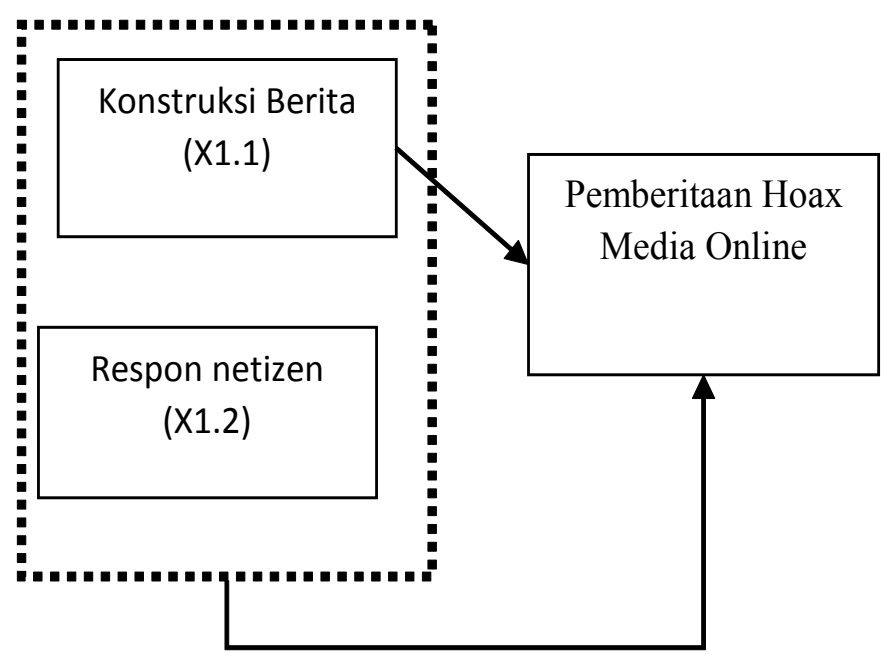


batasan gerak profesional para wartawan akan senantiasa dijadikan sebagai pegangan. Memang untuk menjadi suatu berita yang menarik dan dibaca oleh semua masyarakat, unsur -unsur nilai berita (news value) tetap dijadikan nilai standar oleh wartawan, karena suatu berita yang tidak mempunyai unsur-unsur nilai berita tentunya akan tampil datar dan monoton tanpa makna berarti bagi masyarakat.

Berdasarkan uraian tersebut di atas, maka peneliti mengajukan hipotesis $H_{1}$ sebagai berikut:

H1: Konstruksi Berita berpengaruh positif terhadap Pemberitaan Hoax di Media Online

b. Pengaruh Respon Netizen terhadap Pemberitaan Hoax di Media Online

Respon pada prosesnya didahului sikap seseorang karena sikap merupakan kecendrungan atau kesediaan seseorang untuk bertingkah laku jika menghadapi suatu rangsangan tertentu. Jadi, berbicara mengenai respon atau tidak respon terlepas dari pembahasan sikap. Responjuga diartikan sebagai suatu tingkah laku atau sikap yang berwujud baik sebelum pemahaman yang mendetail, penelitian, pengaruh atau penolakan, suka atau tidak suka serta pemanfaatan pada suatu fenomena tertentu. Secara umum dapat dikatakan bahwa terdapat tiga faktor yang mempengaruhi respon seseorang, yaitu : (a). Diri orang yang bersangkutan yang melihat dan berusaha memberikan interpretasi tentang apa yang dilihatnya itu, ia dipengaruhi oleh sikap, motif, kepentingan, dan harapannya; (b). Sasaran respon tersebut, berupa orang, benda, atau peristiwa. Sifat-sifat sasaran itu biasanya berpengaruh terhadap respon orang melihatnya. Dengan kata lain, gerakan, suara, ukuran, tindakan-tindakan, dan ciriciri lain dari sasaran respon turut menentukan cara pandang orang. (c). Faktor situasi, respon dapat dilihat secara kontekstual yang berarti dalam situasi mana respon itu timbul mendapat perhatian. Situasi merupakan faktor yang turut berperan dalam pembentukan atau tanggapan seseorang. Respon seorang dalam kaitannya dengan isi pemberitaan akan muncul seiring dengan pemahaman pesan yang disampaikan media, sehingga respon akan sangat mempengaruhi pemberitaan yang diterbitkan sebuah media online.

Berdasarkan uraian tersebut di atas, maka peneliti mengajukan hipotesis $\mathrm{H}_{2}$ sebagai berikut:

H2: Respon Netizen Berpengaruh Positif terhadap Pemberitaan Hoax di Media Online

c. Pengaruh Konstruksi Berita dan Respon Netizen secara bersama-sama terhadap Pemberitaan Hoax di Media Online

Pers dengan praktik jurnalistik media massa pun tentu melakukan konstruksi realitas, dan berita merupakan wujud hasil konstruksi realitasnya. Bagi sebagian masyarakat, berita mungkin akan dinilai seperti apa adanya yang terjadi dalam berita, dan seolah pemberitaan tersebut sesuai objektivitasnya. Namun apabila kita cermati lebih dalam, realitas atau peristiwa yang terjadi di sekitar kita telah direkonstruksi dan dibingkai oleh media. Disinilah realitas sosial dimaknai dan menghasilkan maknamakna tertentu, karena jurnalis sebagai pembuat berita, begitu juga pers sebagai lembaga dengan praktik jurnalismenya bisa memengaruhi realitas yang ditemui menjadi sesuai dengan latar ideologinya (konsensus).

Masyarakat mungkin tidak sadar bahwa berita merupakan hasil konstruksi realitas, dan menilai bahwa apa yang telah dibaca dan didengar merupakan benar. Padahal jika ditinjau kedalamannya, media massa melalui jurnalisnya baru saja mendefinisikan ulang realitas yang terjadi sehingga realitas sebenarnya menghasilkan makna-makna tertentu. Media massa 
dalam proses konstruksi berita tentu akan menyiapkan materi konstruksinya yang memiliki koherensi dengan makna yang ingin dimunculkan dalam berita untuk khalayak, sehingga khalayak nantinya bisa bersikap, beropini, dan bertindak sesuai dengan tujuan pemberitaan yang telah dimaknai oleh jurnalis dan media massa.

Pembentukan konstruksi berita dapat dibuat dalam bentuk good news dan bad news. Pada bentuk yang pertama, objek pemberitaan dikonstruksi sebagai sesuatu yang memiliki citra baik dan lebih baik dari yang sesungguhnya. Sedangkan pada bentuk yang ke dua, objek pemberitaan dikonstruksi sebagai suatu hal yang memiliki citra buruk bahkan dibuat lebih buruk dari yang sesungguhnya. Di sinilah media massa mempunyai kekuatan yang penting.

Berdasarkan uraian tersebut di atas, maka peneliti mengajukan hipotesis $\mathrm{H}_{3}$ sebagai berikut:

H3: Konstruksi Berita dan Respon Netizen secara bersama-sama berpengaruh positif terhadap Pemberitaan Hoax di Media Online

\section{Metode Penelitian}

Riset ini menggunakan analisis deskriptif kuantitatif. Teknik pengumpulan data dalam penelitian ini menggunakan teknik pengumpulan data online. Pengumpulan data online yang dimaksud adalah tata cara melakukan penelusuran data melalui media online seperti internet atau media jaringan lainnya yang menyediakan fasilitas online, sehingga memungkinkan peneliti dapat memanfaatkan data-informasi online yang berupa data maupun informasi teori, secepat atau semudah mungkin, dan dapat dipertanggungjawabkan secara akademis. Subjek dalam penelitian ini adalah Netizen yang aktif menggunakan media online serta sering memperhatikan berita yang termuat di detik.com.

\section{Hasil Penelitian dan Pembahasan}

Hasil analisis regresi linier berganda dengan program SPSS ver 21 for windows dimaksudkan untuk menganalisis tentang besarnya pengaruh dari variabel konstruksi berita dan respon netizen terhadap pemberitaan hoax di media online yaitu dengan melihat besar koefisien determinasi (R Square). Dalam penelitian ini terdapat 1 (satu) variabel dependent, yaitu pemberitaan hoax di media online, dan dua variabel independent yaitu konstruksi berita dan respon netizen. Berdasarkan hal tersebut maka metode analisis yang digunakan adalah regresi berganda. Dari analisa regresi yang dilakukan dengan menggunakan bantuan Program SPSS ver 21 for windows yang juga telah dipergunakan untuk uji signifikansi individual atau uji-t diperoleh tabel sebagai berikut.

Berdasarkan tabel dibawah, maka persamaan regresi yang di dapat adalah sebagai berikut:

$$
\begin{aligned}
& \mathrm{Y}=2.198+0,162 \mathrm{X}_{1}+0,145 \mathrm{X}_{2} \\
& \text { Keterangan: } \\
& \mathrm{Y}=\text { Pemberitaan Hoax di Media Online } \\
& \mathrm{X}_{1}=\text { Konstruksi Berita }
\end{aligned}
$$

\begin{tabular}{|c|c|c|c|c|c|c|}
\hline \multirow{2}{*}{\multicolumn{2}{|c|}{ Model }} & \multicolumn{2}{|c|}{$\begin{array}{c}\text { Unstandardized } \\
\text { Coefficients }\end{array}$} & \multirow{2}{*}{$\begin{array}{c}\text { Standardized } \\
\text { Coefficients } \\
\text { Beta }\end{array}$} & \multirow[b]{2}{*}{$\mathrm{t}$} & \multirow[b]{2}{*}{ Sig. } \\
\hline & & B & $\begin{array}{l}\text { Std. } \\
\text { Error }\end{array}$ & & & \\
\hline 1 & (Constant) & 2.198 & 1.771 & & 2.241 & .002 \\
\hline & Konstruksi.Berita & .145 & .221 & .273 & 2.654 & .001 \\
\hline & Respon.Netizen & .162 & .125 & .541 & 3.295 & .000 \\
\hline
\end{tabular}

Tabel 4.1

Analisa Regresi

a Dependent Variable: Pemberitaan.Hoax.di.Media.Online 


\section{$\mathrm{X}_{2}=$ Respon.Netizen}

Persamaan model matematis di atas menunjukkan bahwa pengaruh respon netizen lebih dominan daripada konstruksi berita terhadap pemberitaan hoax di Media Online. Hal itu ditunjukkan dari koefisien regresi respon netizen yaitu 0,162 lebih besar dari koefisien regresi konstruksi berita yang bernilai 0,145 .

\section{Pengujian Hipotesis}

Berdasarkan paradigma penelitian yang telah dikemukakan sebelumnya, dalam penelitian ini akan mengkaji hipotesis secara parsial dan simultan. Untuk menguji hipotesis digunakan uji statistik dengan perhitungan regressi berganda sebagai analisis kuantitatif. Adapun hasil pengujian hipotesis berdasarkan hasil analisis yang telah dikemukakan sebelumnya dapat diuraikan sebagai berikut:

a. Pengaruh Konstruksi Berita terhadap Pemberitaan Hoax di Media Online

Hasil uji signifikansi parsial (uji-t) dengan menggunakan Program SPSS ver 21 for windows dapat dilihat pada tabel 4.1. Berdasarkan tabel tersebut di atas, dapat dilihat bahwa nilai probabilitas signifikansi atau sig.nya adalah 0,001 atau lebih kecil dari 0.05 atau $5 \%$. Selain itu berdasarkan hasil analisis diperileh nilai $t_{\text {hitung }}$ sebesar 2.654 lebih besar dari nilai $\mathrm{t}_{\text {tabel }}$ sebesar 1,969. Karena sig $<0,05$ dan nilai t-hitung lebih besar dari t-tabel maka dikatakan bahwa hipotesis yang berbunyi kontruksi berita berpengaruh positif terhadap pemberitaan hoax di media online dapat dibuktikan. b. Pengaruh Respon Netizen terhadap Pemberitaan Hoax di Media Online

Hasil uji signifikansi parsial (uji-t) dengan menggunakan Program SPSS ver 21 for windows dapat dilihat pada tabel 4.1 Berdasarkan tabel tersebut di atas, dapat dilihat bahwa nilai probabilitas signifikansi atau sig.-nya adalah 0,000 atau lebih kecil dari 0.05 atau 5\%. Selain itu berdasarkan hasil analisis diperoleh nilai $\mathrm{t}_{\text {hitung }}$ sebesar 3.295 lebih besar dari nilai $t_{\text {tabel }}$ sebesar 1,969. Karena sig $<0,05$ dan nilai t-hitung lebih besar dari t-tabel maka dikatakan bahwa hipotesis yang berbunyi Respon Netizen berpengaruh positif terhadap Pemberitaan Hoax di Media Online dapat dibuktikan.

c. Pengaruh Konstruksi Berita dan Respon Netizen terhadap Pemberitaan Hoax di Media Online

Hasil uji signifikansi simultan (uji-F) dengan menggunakan Program SPSS ver 21 for windows adalah sebagai berikut.

Berdasarkan tabel 4.2 tersebut di atas, dapat ketahui bahwa nilai probabilitas signifikansi atau $p$ value-nya adalah 0,000 yang berarti lebih kecil dari 0.05 atau 5\% dan nilai $\mathrm{f}_{\text {hitung }}$ sebesar 27.245 lebih besar dari nilai $\mathrm{f}_{\text {tabel }}$ sebesar 3,879 dengan demikian secara bersama-sama konstruksi berita dan respon netizen memiliki pengaruh positif dan signifikan terhadap pemberitaan hoax di media online.

2. Koefisien Determinasi (Adjusted $\mathrm{R}^{2}$ )

Untuk mengukur seberapa jauh kemampuan variabel bebas dalam menerangkan variabel yang terikat digunakan koefisien

Tabel 2

Hasil Uji Silmutan (Uji-F)

\begin{tabular}{|l|l|r|r|r|r|l|}
\hline \multicolumn{2}{|c|}{ Model } & $\begin{array}{c}\text { Sum of } \\
\text { Squares }\end{array}$ & \multicolumn{1}{c|}{ df } & $\begin{array}{c}\text { Mean } \\
\text { Square }\end{array}$ & F & Sig. \\
\hline 1 & Regression & 147.418 & 2 & 73.709 & 27.245 & $.000(\mathrm{a})$ \\
\hline & Residual & 78.457 & 29 & 2.705 & & \\
\hline & Total & 225.875 & 31 & & & \\
\hline
\end{tabular}

a Predictors: (Constant), Konstruksi.Berita, Respon.Netizen

b Dependent Variable: Pemberitaan.Hoax.di.Media.Online 
Tabel 3

Koefisien Determinasi

\begin{tabular}{|l|c|r|r|r|}
\hline Model & R & R Square & $\begin{array}{c}\text { Adjusted } \\
\text { R Square }\end{array}$ & $\begin{array}{c}\text { Std. Error } \\
\text { of the } \\
\text { Estimate }\end{array}$ \\
\hline 1 & .808 (a) & .653 & .629 & 1.64481 \\
\hline \multicolumn{2}{|l|}{ a Predictors: (Constant), Konstruksi.Berita, Respon.Netizen }
\end{tabular}

determinasi, dari harga $\mathrm{R}^{2}$. Kelemahan mendasar penggunaan koefisien determinasi adalah bias terhadap jumlah variabel independen yang dimasukkan ke dalam model. Oleh karena itu banyak peneliti menganjurkan untuk menggunakan nilai Adjusted $\mathrm{R}^{2}$ pada saat mengevaluasi model regresi yang terbaik. Hasil olah data SPSS ditunjukkan pada tabel diatas.

Berdasarkan tampilan output SPSS model summary atau tabel 3 tersebut di atas, besarnya $\mathrm{R}^{2}$ adalah 0,653 hal ini berarti $65,3 \%$ variabel dependen pemberitaan hoax di media online dapat dijelaskan atau dipengaruhi oleh variabel independen konstruksi berita dan respon netizen, sedangkan sisanya $34,7 \% \quad(100 \%-65,3 \%)$ dijelaskan oleh sebab-sebab yang lain di luar model penelitian.

\section{Simpulan}

Berdasarkan analisis dan pembahasan dapat disimpulkan:

1. Kontruksi berita berpengaruh positif terhadap pemberitaan hoax di media online. Artinya konstruksi berita yang dimuat dan diciptakan oleh media online akan mempengaruhi penyebaran pemberitaan hoax di media online.

2. Respon netizen berpengaruh positif terhadap pemberitaan hoax di media online. Arinya semakin banyak netizen yang merespon pemberitaan hoax, maka peredaraan pemberitaan hoax akan lebih luas dan lebih liar tanpa berpedoman pada tika jurnalitik.

3. Konstruksi berita dan respon netizen memiliki pengaruh positif dan signifikan terhadap pemberitaan hoax di media online. Artinya kedua variabel tersebut memberikan pengaruh yang cukup signifikan dalam pemberitaan hoax di media online.

\section{Daftar Pustaka}

Abdullah, Faiz Sathi,. 2014. "Mass Media Discourse: A Critical Analysis Research Agenda", Journal homepage: $\quad$ http://www.pertanika. upm.edu.my/, Vol,11, No 5. Pp 14.

Abu Ahmadi. 1998. Psikologi Umum. Jakarta: Rineka Cipta

Andy Corry Wardhani Morissan dan Farid Hamid U. 2010. Teori Komunikasi Massa: Media, Budaya, dan Masyarakat. Bogor: Ghalia Indonesia. Bandura, Albert, 2001. "Social Cognitive Theory of Mass Communication", Mediapsychology, Vo 1 . 3 No. 3, Pp. 265-299. Burhan Bungin. 2008. Konstruksi Sosial: Kekuatan Pengaruh Media Massa, Iklan Televisi dan Keputusan Konsumen Serta Kritik Terhadap Peter L. Berger\& Thomas Luckman. Jakarta: Kencana Prenada Media Grup.

Carey, James, 2009. "The concept of discourse in the analysis of complex communication events", The hermeneutic intent is nowhere more neededthan in theoretical discussions of the mass media, Vol. 7, No. 11, Pp. 1-38.

Dalam Werner J. Severin dan James W. Tankard, Jr, 2011. Teori Komunikasi: Sejarah, Metode, dan Terapan di Dalam Media Massa. Cet. Kelima. Jakarta: Kencana.

Denis McQuail. 2011. Teori Komunikasi Massa, Edisi 6 Buku 1. Jakarta: Salemba Humanika.

Fajar Marhaeni. 2009. Ilmu Komunikasi Teori dan Praktik. Jakarta: Graha Ilmu.

Falkheimer, Jesper, 2011. "Events Framed by the Mass Media: Media Coverage 
and Effects of America's Cup Preregatta in Sweden", Event Management, Vol. No. 11, Pp. 81-88.

Griffin, EM. 2006. A First Look at Communication Theory sixth edition. McGraw-Hill. New York.

Herring, Susan C. 2004."Content Analysis for New Media: Rethinking the Paradigm", New Research for New Media: Innovative Research Methodologies Symposium Working Papers and Readings, Vol 2, No. 12, pp. 47-66. http://news.detik.com/read/2902507/hoaxpenculikan-anak-berujung-korban, diakses pada tanggal 13 April 2017. https://news.detik.com/berita/d-3364562/ polis i-cari-pemilik-akunyoutube-yang-sebarkan-isusara-soal-aksi-212? single $=1$

https://www.detik.com/peristiwa/ratnasarumpaet-sby-jokowi-dan-isumakar-gulingkan-pemerintahan.html

Jalaludin Rakhmat, 2008. Psikologi Komunikasi. Bandung. PT. Remaja Rosdakarya.

John M. Echols dan Hassan Shadily. 2005. Kamus InggrisIndonesia:AnEnglish-Indonesian Dictionary. Jakarta: PT Gramedia.

Keong, Yuen Che, Sidra Naim, Noor Darliza Mohamad Zamri. 2014. "Online News Report Headlines of Education Malaysia Global Services", Malaysian Journal of Communication, Vol. 30 No. 2, Pp. 159-182.

Littlejohn, Stephen W. dan Foss, Karen A. 2009. Teori Komunikasi: Theories of Human Communication,9th ed. Penerjemah Mohammad .Yusuf Hamdan. Jakarta: Salemba Humanika. Macnamara,Jim, "Mediacontentanalysis:Itsuses; benefits and best practice methodology", Asia Pacific Public Relations Journal, Vol. 6 No. 1, 2010, Pp. 1-34. Martins, Nicole, Andrew J. Weaver, Daphna Yeshua-Katz, Nicole H. Lewis, Nancy E. Tyree, \& Jakob D. Jensen. 2013. "A Content Analysis of Print News
Coverage of Media Violence and Aggression Research", Journal of Communication, Vol. 1 No. 6, Pp. 1-18. Muljono, Wiryanta, 2012. "Campaign Communication: Qualitative Analysis of the Role of Mass Media and Communication in Interpersonal in Distributed Messages Electricity Energy Conservation", Director of $R$ $\& D$ the Center for ICT Application \& Public Communication, MCIT Indonesia, Vo. 11 No. 16., Pp. 1-15. Nurdin.2004.KomunikasiMassa.Malang:Cespur. Nurudin. 2004. Komunikasi Massa. Yogyakarta:

Cespur.

Onong Uchjana Effendy. 1993. Televisi Siaran Teori dan Praktek. Bandung: PT. Citra Adutya Bakti.. Sioula, Ismini, Georgoulea. 2015. "Approaching Twitter sociologically: a case study of the public humiliat ion of HIV-positiv e women", The Greek Review of Social Research, Vol. 5 No. 2, Pp. 1-27. Stephen W. Littlejohn dan Karen A. Foss. 2009. Teori Komunikasi: Theories of Human Communication. Edisi 9. Jakarta: Salemba Humanika. Syarifudin Yunus. 2010. Jurnalistik Terapan. Bogor: Ghalia Indonesia. Ulinnuha, Roma, Wening Udasmoro, Yahya Wijaya. 2013.“Critical Discourse Analysis: Theory and Method in Social and Literary Framework", Indonesian Journal of Applied Linguistics, Vol. 2 No. 2, pp. 262-274. Wenxiu ,Peng. 2015. "Analysis of New Media Communication Based on Lasswell's "5W" Model", Journal of Educational and Social Research MCSER Publishing, Rome-Italy, Vol. 5 No. 3, Pp. 245-250. WernerJ.SeverindanJames W. Tankard,Jr.Op.Cit. YS. Gunadi. 1988. Himpunan Istilah Komunikasi Edisi Pertama. Jakarta: PT Grasindo anggota IKAPI. 